\title{
Effects of Socio-Demographic Characteristics and Perceived Benefits of Tourism on Community Participation in Tourism in the Mesomagor Area of the Kakum National Park, Ghana
}

\author{
By Ishmael Mensah
}

\begin{abstract}
Community participation in tourism development is essential for their socio-economic well-being and the sustainable management of natural and cultural resources. In view of this, community-Based Ecotourism Projects (CBEPs) have assumed popularity in most parts of the world including Ghana. However, due to the heterogeneity of communities not all community sub-groups have equal opportunity to participate in tourism planning and development. Yet studies on community participation have hardly examined the relationships between peoples' characteristics and their levels of participation in tourism development activities as well as the effects of perceived benefits of tourism on community participation. This study examined the effects of socio-demographic characteristics and perceived impacts on level of participation in tourism development at the Mesomagor Area of the Kakum National Park in Ghana. A survey involving 252 adult community members was conducted. The results of the study show that gender and income were the only socio-demographic variables which significantly related to community participation, with men showing greater participation than women. Also, the effect of perceived economic benefits of tourism on community participation was significant whilst the effect of perceived environmental benefits was insignificant. It is recommended that tourism product in the community should be repackaged to provide income-earning opportunities for farmers.
\end{abstract}

Keywords: community participation, perceived benefits, socio-demographic characteristics, Kakum, Mesomagor.

\section{Introduction}

The community-based ecotourism model has assumed increasing popularity, particularly because of its potential for improving livelihoods, alleviating poverty and fostering environmental conservation in rural communities. Unlike conventional tourism, it entrusts power in the hands of host community members so that they could shape the development of tourism in their communities. This model is even more relevant to communities that fringe national parks and other protected areas. National parks usually do not exist in a vacuum but are surrounded by communities that rely heavily on

\footnotetext{
* Associate Professor, Department of Hospitality and Tourism Management, University of Cape Coast, Ghana.
} 
forest resources for their sustenance. In view of that, experts have predicted that the alienation of people in park-fringe communities from the operations and management of national parks will lead to the loss of commitment by community members to protect the national parks (McLaughlin, 2011). Thus efforts of community members aimed at conserving forests and wildlife will not yield much fruits if local community members are not involved. Also, exclusion of people in host communities from ecotourism development could hamper their socio-economic well-being and the sustainable management of natural and cultural resources, in view of the fact that natural resources are their main source of livelihoods (Mensah \& Adofo, 2013). Therefore the participation of park-fringe communities in tourism development is essential for conservation and protection of national parks. Incorporation of park-fringe communities in the management of national parks has also been seen as a means to empowerment of local people and ensuring successful conservation (Dei, 2000). Community participation has been achieved in many tourism destinations through the medium of Community-based Ecotourism Projects (CBEPs).

The CBEP model is not new to Ghana as it is currently being practiced in a number of communities including Tafi Atome (Afenyo, 2012); Boabeng-Fiema and Tanoboase (Eshun \& Tonto, 2014; Yeboah, 2013); Sirigu (Manu \& Kuuder, 2012); and in communities around the Bobiri Forest such as Krofofrom, Kubease, and Nobewam (Mensah \& Adofo, 2013). Mensah and Adofo (2013) point to the fact that the government of Ghana, through the Forestry Commission and in collaboration with NGOs like the Nature Conservation Research Centre (NCRC) have promoted CBEPs through a number of interventions. In fact the pioneering efforts of the NCRC in creating community-based tourism projects in Ghana has been lauded as meeting the needs of communities better than the models used by National Parks and other protected areas. In collaboration with the Ghana Tourism Authority, Wildlife Division of the Forestry Commission and some donor agencies, NCRC has been able to create community-based tourism projects in 14 communities including Boabeng-Fiema, Sirigu, Tafi-Atome and Bobiri. Their model places the management of tourism in the communities directly in the hands of the local communities through the establishment of tourism management teams. However, even these community-based tourism projects have their own challenges, including inequalities in benefits-sharing (Afenyo \& Amuquandoh, 2014).

Among the benefits of the CBEPs is the ability to shift the attention of community members from the exploitation of forest resources through activities like logging, mining and poaching towards conservation. Participation in the tourism industry provides local people with the motivation for environmental preservation (Harrill, 2004; Tosun, 2006). However, social cohesion is a key factor that determines a community's ability to manage its natural resources and achieve conservation objectives. The reality however is that communities are usually heterogeneous (Blackstock, 2005) comprising of different groups and people with different characteristics and expectations. 
According to Midgley (1986), communities are not homogenous but are made up of individuals and organizations which may have different values, aims and objectives. The dynamics of heterogeneous community groups are such that not all community sub-groups have an equal opportunity to participate in tourism planning (Khazaei et al., 2015). Usually, the elite who have a higher status in the community are more likely to have greater participation in tourism development and are not likely to always act in the best interest of other community members.

In spite of the fact that communities are usually made up of people with different characteristics and perceptions, studies on community participation have hardly examined the relationships between peoples' characteristics and their levels of participation in tourism development activities. There have been a plethora of studies that examined residents' perceptions of the impacts of tourism development but Nicholas et al. (2009) are of the view that the effects of such perceptions on community participation in tourism have been ignored to a large extent. There have been a modicum of studies on tourism in the Kakum Conservation Area but those studies have largely centred on the livelihoods of the communities and issues relating to conservation of the forest and its resources. Thus there is a dearth of studies examining the factors that influence community participation. It is against this background that this study seeks to examine the effects of socio-demographic characteristics and perceived benefits of tourism on level of participation in tourism development at the Mesomagor Area of the Kakum National Park in Ghana.

\section{Literature Review}

\section{Community Participation in Tourism Development}

Communities reflect both geographical and social spheres. In this regard Aas et al. (2005, p. 30) defined a community as "a geographical area, or a group of people with shared origins or interests". In the same vein, Manderson et al. (1992) referred to it as a population which is geographically focused but which also exists as a discrete social entity, with a local collective identity and corporate purpose. Thus merely occupying a geographical space does not qualify a group of people to be classified as a community. There is the need for people in a community to have some cohesion and shared aspirations because when individuals and groups work together to address common problems, they experience improvements in their progress and well-being (Theodori, 2005).

In recognition of the fact that communities are not homogeneous but composed of different groups of people, Schafft \& Greenwood (2003) refer to participation as the inclusion of different segments of community members in an on-going community development process. It is a process whereby "people, in partnership with each other and those able to assist them, identify problems and needs, mobilise resources, and assume responsibility to plan, manage, control and assess the individual and collective actions that they themselves 
decide upon" (Bretty, 2003, p.5). Jaafar et al. (2015) define community participation in the context of tourism development as the process whereby the community influences the direction of tourism development rather than simply being passive recipients of its benefits.

One form of tourism which is closely associated with community participation is ecotourism; specifically CBETs. Drumm (1998) defined community participation in ecotourism development as ecotourism projects which are undertaken under the control and with the active participation of local people who occupy or own a natural attraction. Chok et al. (2007, p. 147) have also opined that host communities must participate in decisions on tourism development in their communities if their livelihood priorities are to be reflected in the way tourism is developed. However, community participation is not limited to only participation in decision-making. Two forms of community participation have been identified, namely participation in the decision making process and participation in the benefits of tourism (McIntosh \& Goeldner, 1986; Timothy, 1999). Ashley \& Roe (1998) also suggest that community participation in ecotourism development and management could range from the individual to the whole community, and could include various activities such as employment, supply of goods and services, community enterprise ownership and joint ventures. Tosun (2005) aptly describes the term "community participation" as a categorical term that validates different forms (direct, indirect, active, passive, etc.) of participation at different levels (local, regional and national) under particular circumstances.

Participation in employment opportunities is seen as a way to involve and attract community participation and ultimately the support of community members for tourism development (Zhao \& Ritchie, 2007). It is also a way of helping local communities to derive economic and other benefits (Tosun, 2000). Yet, Botes \& Rensburg (2000) argue that though community participation in development is advocated for various noble reasons it is often permeated by empty rhetoric and little impact.

\section{Socio-Demographics and Community Participation}

Socio-demographic characteristics such as age and gender have been found to influence residents' attitudes towards tourism development in general (Harrill, 2004). In the same vein, studies have shown that socio-demographic characteristics have some influence on community participation in tourism as such different resident groups tend to have different attitudes towards participation in tourism activities (Kibicho, 2008). Kibicho (2008) compared the perceptions of community involvement among different resident groups, who were classified according to demographic characteristics such as age, origin, level of education and gender. The results showed that 'operatives' were interested in participation in the project's activities, 'opinion leaders' were concerned about the benefits derived by the community from the project while 'official leaders' valued the success of the project. In a related study, Safari et al. (2015) found out that age, sex and level of education of an individual were 
determinants of involvement in tourism related activities. They found out that more men compared to women, middle-aged respondents and those who had attained tertiary education were more involved in tourism-related activities.

Jaafar et al. (2015) also found out that that both gender and age had significant moderating effects on the relationship between residents' positive perceptions of tourism and their participation. Men generally are more predisposed to participating in developmental processes than their female counterparts, to this end, Guijt \& Shah (1998) lamented the poor participation of women in development programmes of many agencies. Greene (2005) also asserts that women from more deprived backgrounds often experience low selfconfidence which acts as a barrier to their participation (Greene 2005). Mehta \& Kellert (1998) in a study on local attitudes toward community-based conservation policy and programmes in Makalu-Barun Conservation Area in Nepal, found out that gender had a significant effect on favourable attitude towards community forestry, with women being less supportive. With regards to the effect of age on participation in tourism, Trakolis (2001) found out in Prespes Lakes National Park, Greece, that people's perceptions about tourism planning in the park were significantly different across age groups.

Previous studies have also provided evidence to the fact that income and education influence community participation in tourism (Odege, 2014; Yeboah, 2013). Income and level of education essentially determine one's status or social class in a community. The socio economic group a person belongs to has an impact on his/her level of participation and the type of participation he/she is involved in because people from lower socio economic groups often have less access to resources and practical support making participation difficult (Brodie et al. 2009).

Simmons (1994) noted that education can both heighten the public's confidence and increase their ability to effectively participate. It is against this background that Cole (2006) suggested that the barriers to active local participation might result from low educational level and unfair power distribution. In a study on factors influencing community participation in cultural tourism at Kit Mikayi in Kisumu County, Kenya, Odege (2014) found out that there was a significant relationship between residents' household income as well as their level of education and participation in cultural tourism. Also, Yeboah (2013) in a study on the extent of community participation in selected Community- Based Ecotourism Projects in the Brong-Ahafo Region of Ghana found out that significant differences existed in the levels of participation of community members in terms of their levels of education and income in the areas of decision-making, implementation as well as monitoring and evaluation. Salleh et al. (2016) also found income in addition to encouragement from family to be the two factors that influenced participation in tourism-related businesses by local communities on Langkawi Island.

Perceived Benefits of Tourism and Community Participation 
Studies have shown that perceived impacts of tourism has significant effects on host community's attitudes toward tourism and their level of support of tourism activities in their communities (Byrd 2003; Wang et al., 2007; Yoon et al., 1999) and their perceptions of tourism (Mehta \& Heinen, 2001).

Residents' perception of the impacts of tourism has implications for community participation (Ko \& Stewart, 2002). Goodman et al. (1998) posits that a community's sense of the costs and benefits associated with participation could determine their participation in development. Gursoy et al. (2002) argue that residents with positive perceptions of tourism impacts are more likely to engage in tourism development, thereby positively affecting community participation. On the other hand, those with negative perceptions are more likely to discourage community participation. Page et al. (1998) on the other hand, are of the view that usually local communities lack knowledge on the scale, volume and economic significance of cultural tourism and this results in their lack of enthusiasm in participating in tourism development and this translates into less than expected benefits for local communities.

Jaafar et al. (2015) found out that socio-cultural impacts of tourism development had a strong positive effect on community participation. Hibbard \& Lurie (2000) pointed to the fact that in Jackson/Teton County in Wyoming, locals who had lots of economic and environmental concerns about tourism were those who had great passion for participation in tourism. Nyaupane et al. (2006) in a comparative study of Yunnan and Annapurna came to the conclusion that residents in Annapurna were more aware of the increasing economic benefits tourism brought, so they participated more actively. Maraga et al. (2010) in a study in the Nyando River Basin also found out that there was a strong positive relationship between community participation and the benefits obtained from the afforestation projects. However, in a related study by Hung et al. (2011) they did not find any significant effect of perceived benefits on community participation though level of awareness and knowledge of tourism development had a significant effect on community participation. Other studies have suggested that the relationship between residents' perceptions of the impacts of tourism and community participation is not linear but it is moderated by the characteristics of residents (Easterling, 2005; La'tkova' \& Vogt, 2012).

\section{Methodology}

\section{Study Area}

The Mesomagor Area comprises of a village (Mesomagor) and two adjoining hamlets (Affulkrom and Seidukrom) which lie on the eastern border of the Kakum National Park. Kakum National Park which was officially opened in 1994 is a $366 \mathrm{Km}^{2}$ moist semi-deciduous forest rich in both flora and fauna. It is located in the Central Region of Ghana, specifically the Twifo 
Heman Lower Denkyira and Assin Districts at approximately 35 kilometers north of Cape Coast, the capital city of the Central Region of Ghana.

It is one of the communities fringing the Kakum National Park which has a community-based tourism project. This is as a result of an initiative by Conservation International in 1999 to establish a community-based tourism project which included a treehouse, bamboo orchestra performances, guided tours of the community and hiking through the forest. Appiah-Opoku (2011) avers that among the communities on the boundaries of the Kakum National Park, Mesomagor is the only community which has been innovative in creating a community-based ecotourism plan to attract tourists and generate revenue.

\section{Research Design}

Cross-sectional design is useful when collecting data at a point in time to describe prevailing conditions and relationships between variables at a place. This is exactly what this study sought to do, to collect data on community participation at Mesomagor Area at a particular point in time. In view of the cross-sectional design, the researcher followed the steps proposed by Kumar (2002) which were deciding on what to find out; identifying the study population and selecting a sample; and contacting respondents to elicit the required information. This paper employed quantitative research which is a scientific process that involves the collection of numerical data which can be subjected to statistical analysis.

\section{Data and Instrument}

This study involved the collection of primary data from community members in the Mesomagor Area through the administration of questionnaires in line with the survey method. Primary data on communities' perceptions of the economic and environmental benefits of tourism as well as the extent of their participation in tourism were collected.

The questions were classified into three modules. Module A questions were on community participation. Module $\mathrm{B}$ was on the economic and environmental benefits of tourism whilst Module $\mathrm{C}$ elicited information on the socio-demographic characteristics of respondents. Based on the literature reviewed a scale was developed for measuring community participation in tourism development. The degree of personal participation of respondents in different aspects of tourism development in the community was measured using a 4-point rating scale ranging from 'never' to 'frequently'. The perceived benefits of tourism was also measured based on a set of statements relating to economic and environmental benefits derived from tourism by the community, employing a 5-point likert scale ranging from strongly disagree to strongly agree.

\section{Population and Sampling Procedure}


The target population for this study was all residents of the Mesomagor Area who were 18 years or more. To obtain the population of adult residents in the community, all households were numbered by the researcher and two field assistants. There were 80 households in Mesomagor, 17 in Affulkrom and 33 in Seidukrom totalling 130 houses. The adults in each household were then listed. This resulted in a total of 310 adults comprising 178 from Mesomagor, 42 from Affulkrom and 71 from Seidukrom. In terms of gender composition, there were 157 males and 153 females. To ensure representativeness of both male and female community members, two adults comprising of a male and female were randomly sampled from each household except for those houses with only male or female adults. It was a representative sample of $90 \%$ of the adult population of the community. This was made up of 160 from Mesomagor, 36 from Affulkrom and 64 from Seidukrom. By the end of the survey, 252 respondents made up of 158 from Mesomagor, 35 from Affulkrom and 59 from Seidukrom took part in the study representing a response rate of $97 \%$. Patton (1990) is of the view that a sample size depends on what the researcher wants to know, the purpose of the study, what is at stake, what will be useful, what will be credible and what can be done with available time and resources. These were the considerations made in arriving at the sample size.

\section{Data Collection Procedure}

Prior to the actual data collection, a pre-test was undertaken in Abrafo Odumase one of the communities on the south-western border of the park. This was to ascertain the validity and reliability of the instrument and to identify challenges that were likely to emerge during the main survey. At Abrafo, questionnaires were administered to a total of 25 residents. This afforded the researcher the opportunity to firm up the instruments for the actual data collection. The results of the pre-test also indicated that the scales used in the instrument were reliable.

Data collection lasted for a period of three weeks. Permission to conduct the study was sought from the Chief and elders of the community during which drinks were presented to the Chief as tradition demanded. There is an Akan adage that 'one does not go to the chief's palace with empty hands'. The chief and elders were helpful in informing community residents about the researcher's mission and soliciting cooperation from them. The questionnaires were interviewer-administered by the researcher and three trained Field Assistants due to the inability of most respondents to read and comprehend the questions. In order to ensure inter-interviewer reliability, a training session was organised for the Field Assistants during which the instrument was translated into the local dialect (Twi) and the researcher together with the Field Assistants agreed on exactly how the questions should be interpreted. Apart from Tuesdays when most residents did not go to farm, questionnaires were usually administered in the evenings and weekends when respondents were available in their homes. In cases where selected respondents were not available, 
researchers had to return at another date. This was done to ensure a high level of response.

\section{Data Processing and Analysis}

Data analysis began with editing of completed questionnaires for consistency in answers by respondents. Data were analysed using statistical software: Statistical Product for Service Solutions (SPSS) Version 21. SPSS enabled easy computation of percentages and frequencies to illustrate the analysis. The relationship between socio-demographic variables and perceived benefits of tourism on community participation was tested using chi-square and a linear regression model respectively.

\section{Results and Discussion}

\section{Socio-Demographic Characteristics of Respondents}

From Table 1, a slight majority (51.2\%) of respondents were males whilst $48.8 \%$ were females. Their ages mostly ranged between $30-49$ years $(43.7 \%)$ which represents the very active age group, with only $4.8 \%$ below 20 years. Educational attainment was however on the lower level with those with basic education dominating with $25 \%$ and $44 \%$ having completed primary and secondary schools respectively. Also, an appreciable number of the respondents $(23 \%)$ were not literate as they had not received any form of formal education. Additionally, in terms of religion, they were predominantly Christians (94\%) whilst the dominant occupation was farming (84.9\%). More than half (54\%) had household sizes ranging from 6-10. Most of the respondents $(44.6 \%)$ had lived in the community for between 16-30 years.

\section{Community Participation in Tourism}

The results of the study indicated a low level of participation in tourism by community members. They rarely participated in tourism development (Overall mean $=1.53)$ as shown in Table 2 . Overall, $70 \%$ of respondents had never participated in tourism development while only $4.4 \%$ frequently participated in it. These are people in full-time and part-time employment in the tourism industry as Tour Guides and Forest Guards. Interestingly, one-third of respondents $(33.3 \%)$ had never come into direct contact with tourists (Mean $=2.27, \mathrm{SD}=1.06$ ). Apparently these are people who are completely insulated from the tourism industry at the Mesomagor Area and thus could not partake in tourism development. Even for most of those who come into contact with the tourists, the acquaintance appeared to be cursory and passive.

The majority of respondents had neither provided any service to tourists $(67.1 \%)$ nor attended any meeting to discuss tourism issues (71\%). Also, $74.2 \%$ had never taken part in decisions on tourism development. It is also 
evident that a greater majority of the respondents $(80.2 \%)$ were not involved in the management of tourism in the community. Participation in the benefits of tourism in either cash or kind appears to be the least, with $88.5 \%$ claiming they had never shared in the benefits of tourism (Mean $=1.18, \mathrm{SD}=0.56)$.

Table 1. Socio-Demographic Characteristics of Respondents

\begin{tabular}{|c|c|c|}
\hline Characteristics & Frequency & Percent \\
\hline \multicolumn{3}{|l|}{ Gender } \\
\hline Male & 129 & 51.2 \\
\hline Female & 123 & 48.8 \\
\hline \multicolumn{3}{|l|}{ Age } \\
\hline Below 20 years & 12 & 4.8 \\
\hline $20-39$ years & 64 & 25.4 \\
\hline $30-49$ years & 110 & 43.7 \\
\hline 50 years and above & 66 & 26.2 \\
\hline \multicolumn{3}{|l|}{ Educational level } \\
\hline None & 58 & 23 \\
\hline Primary & 63 & 25 \\
\hline Junior Secondary/middle & 111 & 44 \\
\hline Senior secondary & 19 & 7.5 \\
\hline Tertiary & 1 & 0.4 \\
\hline \multicolumn{3}{|l|}{ Religion } \\
\hline Christian & 237 & 94 \\
\hline Muslim & 13 & 5.2 \\
\hline Traditionalist & 2 & 0.8 \\
\hline \multicolumn{3}{|l|}{ Household size } \\
\hline $1-5$ & 100 & 39.7 \\
\hline $6-10$ & 136 & 54 \\
\hline $11-15$ & 12 & 4.8 \\
\hline 16 or more & 4 & 1.6 \\
\hline \multicolumn{3}{|l|}{ Length of stay in community } \\
\hline $1-15$ years & 53 & 21.1 \\
\hline 16-30 years & 112 & 44.6 \\
\hline $31-45$ years & 71 & 28.3 \\
\hline 46-60 years & 11 & 4.4 \\
\hline 61 or more years & 4 & 1.6 \\
\hline \multicolumn{3}{|l|}{ Occupation } \\
\hline Unemployed & 6 & 2.4 \\
\hline Student & 10 & 4.0 \\
\hline Teacher & 4 & 1.6 \\
\hline Farmer & 214 & 84.9 \\
\hline Artisan & 9 & 3.6 \\
\hline Driver & 1 & 0.4 \\
\hline Seller/trader & 6 & 2.4 \\
\hline Forestry & 1 & 0.4 \\
\hline Tourism & 1 & 0.4 \\
\hline
\end{tabular}

Source: Field Work, 2015 
Table 2. Level of Participation in Tourism by Respondents

\begin{tabular}{|l|c|c|c|c|c|c|}
\hline Variable & $\begin{array}{c}\text { Never } \\
(\%)\end{array}$ & $\begin{array}{c}\text { Rarely } \\
(\%)\end{array}$ & $\begin{array}{c}\text { Occasionally } \\
(\%)\end{array}$ & $\begin{array}{c}\text { Frequently } \\
(\%)\end{array}$ & Mean & SD \\
\hline $\begin{array}{l}\text { Come into direct } \\
\text { contact with tourists }\end{array}$ & 33.3 & 19.0 & 34.5 & 13.1 & 2.27 & 1.06 \\
\hline $\begin{array}{l}\text { Provide some } \\
\text { services or sell } \\
\text { products to tourists }\end{array}$ & 67.1 & 14.3 & 16.3 & 2.4 & 1.57 & 1.03 \\
\hline $\begin{array}{l}\text { Attend meetings to } \\
\text { discuss tourism } \\
\text { issues }\end{array}$ & 71.0 & 11.1 & 11.9 & 6.0 & 1.53 & 0.92 \\
\hline $\begin{array}{l}\text { Take part in } \\
\text { decisions on tourism } \\
\text { development }\end{array}$ & 74.2 & 11.1 & 11.9 & 2.8 & 1.43 & 0.81 \\
\hline $\begin{array}{l}\text { Earn income from } \\
\text { the tourism industry }\end{array}$ & 76.2 & 11.5 & 10.3 & 2.0 & 1.38 & 0.75 \\
\hline $\begin{array}{l}\text { Involved in the } \\
\text { management of } \\
\text { tourism }\end{array}$ & 80.2 & 8.7 & 7.9 & 3.2 & 1.34 & 0.76 \\
\hline $\begin{array}{l}\text { Share in the benefits } \\
\text { of tourism }\end{array}$ & 88.5 & 6.0 & 4.4 & 1.2 & 1.18 & 0.56 \\
\hline Overall & 70.0 & 11.7 & 13.9 & 4.4 & 1.53 & 0.84 \\
\hline Bara & & & & \\
\hline
\end{tabular}

Based on a scale of 1-4 (never- frequently)

Source: Fieldwork, 2015

The low level of participation in tourism development in spite of the community-based tourism project at Mesomagor Area could be attributed to the scale of tourism development in the community coupled with the structure of management of the tourism project. Mesomagor does not lie along the main entrance route to the Kakum National Park but on the eastern boundary of the park. It is a relatively unknown destination as such tourist arrivals had been intermittent and paltry. The community did not have the facilities to receive tourists on even a modest scale. The treehouse could only accommodate a maximum of eight people at a time whilst the guesthouse could only accommodate 12 people at a time. It is therefore not surprising that some $33 \%$ of respondents had never come into contact with the tourists. Under such circumstances, tourism provides very little employment and other socioeconomic benefits for community members.

Community participation in meetings, decision-making and management of tourism was also low because by the structure of the Mesomagor project, it is a management committee that is supposed to play that role and not the generality of community members. Four people from the community comprising of a Community Tour Guide, leader of the Bamboo Orchestra, the Reception Manager at the treehouse and one elder who represents the traditional authority were members of the management committee. 


\section{Perceived Benefits of Tourism in Community}

The preponderant opinion was that the establishment of the national park had derived more conservation benefits than economic benefits. On the average, whilst respondents disagreed that they had derived economic benefits (Mean $=1.84)$, they strongly agreed that it had enhanced the conservation of the forest (Mean $=3.68$ ). More than half of respondents $(57.1 \%)$ strongly disagreed that tourism at the park had provided employment opportunities for people in the community (Mean $=1.77, \mathrm{SD}=1.12$ ). They also disagreed that it had increased the income of community members (Mean $=1.77, \mathrm{SD}=1.05$ ), increased the quality of products and services they consume (Mean $=2.34$, SD $=1.29$ ), increased the number of infrastructure projects in the community (Mean $=1.89, \mathrm{SD}=1.03)$ and improved the quality of healthcare facilities in the community (Mean $=1.99, \mathrm{SD}=1.00)$.

Table 3. Perceived Economic and Environmental Benefits of Tourism

\begin{tabular}{|c|c|c|c|c|c|c|c|}
\hline & SD & D & $\mathbf{N}$ & $\mathbf{A}$ & $\mathbf{S A}$ & Mean & $\begin{array}{l}\text { Std. } \\
\text { Dev. }\end{array}$ \\
\hline \multicolumn{8}{|l|}{ Economic benefits } \\
\hline $\begin{array}{l}\text { Provided employment opportunities for } \\
\text { people in my community }\end{array}$ & 57.1 & 25.4 & 2.0 & 13.9 & 1.6 & 1.77 & 1.12 \\
\hline $\begin{array}{l}\text { Increased the income of community } \\
\text { members }\end{array}$ & 54.2 & 28.7 & 3.2 & 13.5 & 0.4 & 1.77 & 1.05 \\
\hline $\begin{array}{l}\text { Increased the quality of products and } \\
\text { services consumed by community } \\
\text { members }\end{array}$ & 40.5 & 15.1 & 14.7 & 29.4 & 0.4 & 2.34 & 1.29 \\
\hline $\begin{array}{l}\text { Increased the number of infrastructural } \\
\text { projects in this community }\end{array}$ & 43.3 & 40.1 & 1.2 & 15.5 & 0.0 & 1.89 & 1.03 \\
\hline $\begin{array}{l}\text { Improved the quality of healthcare } \\
\text { facilities in this community }\end{array}$ & 35.7 & 44.4 & 5.6 & 13.9 & 0.4 & 1.99 & 1.00 \\
\hline $\begin{array}{l}\text { Benefited other industries in this } \\
\text { community }\end{array}$ & 44.0 & 32.3 & 5.6 & 17.3 & 0.8 & 1.99 & 1.13 \\
\hline $\begin{array}{l}\text { Provided business opportunities for local } \\
\text { producers }\end{array}$ & 43.5 & 36.7 & 8.1 & 11.3 & 0.4 & 1.88 & 0.20 \\
\hline $\begin{array}{l}\text { Provided skills training for community } \\
\text { members }\end{array}$ & 66.3 & 27.0 & 2.4 & 4.4 & 0.0 & 1.45 & 0.75 \\
\hline $\begin{array}{l}\text { Helped to reduce poverty in this } \\
\text { community }\end{array}$ & 63.7 & 28.3 & 1.2 & 6.8 & 0.0 & 1.51 & 0.83 \\
\hline Category mean & & & & & & 1.84 & \\
\hline \multicolumn{8}{|l|}{ Environmental benefits } \\
\hline Protected wildlife & 2.4 & 0.4 & 2.4 & 36.8 & 58.0 & 4.48 & 0.78 \\
\hline $\begin{array}{lll}\begin{array}{l}\text { Protected } \\
\text { environment }\end{array} & \text { community's } & \text { natural } \\
\end{array}$ & 0.0 & 8.8 & 11.6 & 55.8 & 23.9 & 3.95 & 0.84 \\
\hline Created environmental awareness & 0.8 & 6.0 & 24.2 & 52.4 & 16.7 & 3.78 & 0.82 \\
\hline $\begin{array}{l}\text { Conserved the environment in my } \\
\text { community }\end{array}$ & 0.4 & 7.9 & 14.3 & 71.4 & 6.0 & 3.75 & 0.70 \\
\hline Preserved the culture of my community & 9.6 & 8.4 & 14.3 & 59.0 & 8.8 & 3.49 & 1.08 \\
\hline $\begin{array}{l}\text { Improved the level of sanitation in my } \\
\text { community }\end{array}$ & 32.3 & 15.7 & 11.3 & 38.7 & 2.0 & 2.63 & 1.33 \\
\hline Category mean & & & & & & 3.68 & \\
\hline
\end{tabular}

Source: Fieldwork, 2015 
According to community members, the creation of the park had not provided further opportunities for development and poverty alleviation. In fact, nearly two-thirds (63.7\%) of respondents strongly agreed that tourism had helped to reduce poverty in their communities (Mean $=1.51, \mathrm{SD}=0.83$ ). They indicated that tourist inflows into the community had not benefited industries in the community (Mean $=1.99, \mathrm{SD}=1.13$ ). They also disagreed that it had provided business opportunities for local producers (Mean $=1.88, \mathrm{SD}=0.20$ ). One of the potential benefits of community-based ecotourism is skills training. However, $66.3 \%$ strongly disagreed that the ecotourism in their communities had led to the provision of skills training for community members (Mean = $1.45, \mathrm{SD}=0.75$ ).

The responses however show that one area that ecotourism at the KNP has achieved is the conservation of the forest ecosystem. The strongest agreement was to the fact that ecotourism at KNP had led to the protection of wildlife as $58 \%$ of respondents strongly agreed to this (Mean $=4.48, \mathrm{SD}=0.78$ ). They also strongly agreed that ecotourism had led to the protection of their communities' natural environment (Mean $=3.95$, SD $=0.84)$, created environmental awareness (Mean $=3.78, \mathrm{SD}=0.82)$ and helped to conserve the environment in their communities (Mean $=3.75, \mathrm{SD}=0.70$ ). Apart from the natural environment, ecotourism had also helped to preserve the culture of the community (Mean $=3.49, \mathrm{SD}=1.08$ ) as evident in the activities of the Bamboo Orchestra. However, as to whether ecotourism had helped to improve the level of sanitation in their communities, there was divided opinion (Mean = $2.63, \mathrm{SD}=1.33$ ).

\section{Relationship between Socio-Demographic Characteristics and Community Participation}

The relationship between socio-demographic characteristics and community participation was tested employing the chi-square test $\left(x^{2}\right)$ of goodness-of-fit. The result of the analysis as presented in Table 4 indicates that gender and income were the only socio-demographic variables which were significantly related to community participation at the $p \leq 0.05$ significance level. The other socio-demographic variables namely, level of education, age and marital status however did not have any significant relationship with community participation.

The relationship between gender and community participation was significant at the $\mathrm{p} \leq 0.05$ significance level $\left(x^{2}=27.78, p=0.00\right)$. Males tended to show greater participation in tourism development than their female counterparts, which reaffirms the fact that men are more inclined to participating in development than their female counterparts especially in a patriarchal society (Guijt \& Shah, 1998; Mehta \& Kellert, 1998). Mesomagor area is a typical patriarchal community where men are at the forefront of most developmental activities including tourism. For instance, there was no woman on the Tourism Development Committee of the community. As much as $93.5 \%$ of females indicated a lower degree of participation in tourism development 
compared to $68.2 \%$ of their male counterparts. Also, whiles $10.9 \%$ of males had high levels of participation in tourism development, none of the females fell into that category.

Table 4. Chi-Square Analysis of Relationship between Socio-Demographics and Community Participation in Tourism

\begin{tabular}{|l|c|c|c|l|l|}
\hline $\begin{array}{l}\text { Socio-demographic } \\
\text { characteristic }\end{array}$ & \multicolumn{3}{|c|}{$\begin{array}{c}\text { Degree of participation in } \\
\text { tourism }\end{array}$} & $\boldsymbol{x}^{2}$ & $\begin{array}{c}p \text { - } \\
\text { value }\end{array}$ \\
\hline & Low & Moderate & High & & \\
\hline Gender & & & & & \\
Male & 68.2 & 20.9 & 10.9 & 27.78 & 0.00 \\
Female & 93.5 & 6.5 & 0.0 & & \\
\hline Age (years) & & & & & \\
$\quad<20$ & 91.7 & 8.3 & 0.0 & 9.71 & 0.14 \\
20-39 & 89.1 & 9.4 & 1.6 & & \\
30-49 & 80.9 & 12.7 & 6.4 & & \\
50+ & 69.7 & 21.2 & 9.1 & & \\
\hline Education & & & & & \\
No formal education & 87.9 & 10.3 & 1.7 & 8.54 & 0.07 \\
Primary & 85.7 & 12.7 & 1.6 & & \\
Secondary/tertiary & 74.8 & 16.0 & 9.2 & & \\
\hline Marital status & & & & & \\
Single & 80.5 & 14.6 & 4.9 & 5.93 & 0.43 \\
Married & 77.8 & 15.3 & 6.8 & & \\
Widowed & 91.3 & 8.7 & 0.0 & & \\
Divorced/separated & 100.0 & 0.0 & 0.0 & & \\
\hline Income (GH $\phi)$ & & & & & \\
<100 & 73.9 & 21.7 & 4.3 & 10.09 & 0.04 \\
100-199 & 66.7 & 22.2 & 11.1 & & \\
200+ & 40.0 & 36.0 & 24.0 & & \\
\hline
\end{tabular}

Source: Fieldwork, 2015

There was also a significant relationship between income levels and community participation. The results in Table 4 indicate that the higher the income of a respondent, the greater the participation in tourism development $\left(x^{2}=10.09, \mathrm{p}=0.04\right)$. For instance, $73.9 \%$ of those who earned less than $\mathrm{GH} \notin 100$ had a low participation in tourism development compared to $40 \%$ of those who earned $\mathrm{GH} \notin 200$ or more. On the other hand, whilst $24 \%$ of those who earned $\mathrm{GH} \phi 200$ or more had high participation in tourism development, only $4.3 \%$ of those who earned less than $\mathrm{GH} \notin 100$ fell into that category. This result supports the findings of Odege (2014) and Yeboah (2013) who provided evidence from an African context to the effect that income has a significant effect on community participation in tourism. The significant effect of respondents' income on community participation could be attributed to the fact that respondents with higher incomes are more likely to be those who supplement their incomes with incomes from the tourism industry. Thus the greater the likelihood that they will participate in tourism development. 


\section{Effects of Perceived Benefits of Tourism on Community Participation}

The regression model on the effect of perceived benefits of tourism on community participation was significant, with perceived benefits of tourism explaining $5.8 \%$ of the variance in community participation $\left(R^{2}=0.058 ; F=\right.$ 7.152; $\mathrm{p}=0.001)$ as shown in Table 5. The effect of perceived economic benefits of tourism on community participation was significant $(\beta=1.96 ; p=$ 0.005 ) indicating that the more favourable the perception that tourism provides economic benefits to the communities, the greater the participation in tourism. This coincides with the findings of Gursoy et al., (2002) and Jaafar et al. (2015).

Table 5. Linear Regression Analysis for Effects of Perceived Benefits of Tourism on Community Participation

\begin{tabular}{|l|c|c|c|c|}
\hline Variable & $\boldsymbol{B}$ & $\boldsymbol{S E} \boldsymbol{B}$ & $\boldsymbol{\beta}$ & $\boldsymbol{p}$ \\
\hline Constant & 4.723 & 1.525 & $\overline{ }$ & 0.002 \\
Perceived economic impacts & 0.087 & 0.031 & 1.96 & 0.005 \\
Perceived environmental impacts & 0.084 & 0.075 & 0.079 & 0.261 \\
\hline$F$ Value & & 7.152 & & 0.001 \\
\hline$R^{2}$ & & 0.058 & & \\
\hline Adj. $R^{2}$ & & 0.050 & & \\
\hline
\end{tabular}

Source: Fieldwork, 2015

However, the effect of perceived environmental benefits on community participation was not significant $(\beta=0.079 ; p=0.261)$. Community members' perception of the environmental benefits of tourism in their community was not a good predictor of their participation in tourism development. This is perhaps due to the fact that though community members thought the creation of the Kakum National Park had resulted in some environmental benefits, they did not see themselves as direct beneficiaries. To them the conservation of the forest and its resources did not improve their livelihoods. It has rather worsened their economic situation (Abane et al., 1999). Due to the ban on hunting and harvesting of other forest products they were worse off. Though conservation of the forest is good, for community members, it is a price they have to pay for tourism development. Goodman et al.'s (1998) assertion that a community's sense of the costs and benefits associated with participation can determine whether they participate in development or not could not have been truer.

\section{Conclusions and Recommendations}

This study has provided evidence to the fact that community participation in tourism development is related to the gender and income of community members. This underscores the need for gender and income earning considerations in community-based tourism projects in order to elicit maximum participation from communities and to diffuse apathy. It has 
emerged from this study that men are more inclined to participate in tourism development at the community level than their female counterparts. The relatively low participation by women could be attributed to the structure of patriarchal societies such as the Mesomagor Area where women have generally been relegated to the background of community development. Gender roles are clearly defined and women as homemakers are expected to undertake domestic chores whiles their male counterparts engage in the broader communal activities. This is also coupled with the fact that there are limited opportunities for participation by women because the volume of tourist arrivals and tourist activities in the community in general are low. For greater opportunities for participation to be ensured, there is the need to repackage the product and integrate it into the tour itinerary of the Kakum National Park. Since most community members are farmers, a farm tourism package could prove more beneficial; it can elicit greater participation from community members and provide supplementary incomes for farmers.

The study also shows that the greater the perceived economic benefits of tourism, the greater the participation in tourism development by community members. Thus the tourism project in the community must provide tangible economic benefits to ensure greater participation by community members. A greater share of revenue derived from tourism should be invested in social infrastructure such as schools, clinics and roads. Also, part of the tourism revenue could be used to support farmers with farming inputs to help improve upon their yield. Finally, future studies should employ a qualitative approach to unearth the reasons for participation or non-participation in community based tourism projects. This study focused on a single community. It will be more insightful to sample from different communities along the catchment area of the Kakum National Park in a more comprehensive study.

\section{References}

Aas, C., Ladkin, A., \& Fletcher, J. (2005). Stakeholder collaboration and heritage management. Annals of Tourism Research, 32(1), 28-48.

Abane, A. M., Awusabo-Asare, K., \& Kissi, A. K. (1999). In whose interest? Individual and societal needs in the creation of forest reserves: The case of Kakum in Ghana. Bulletin of the Ghana Geographical Association, 21, 21- 30.

Afenyo, E. A. (2012). Community participation in ecotourism, Evidence from Tafi Atome, Ghana. African Journal of Hospitality, Tourism and Leisure, 2(2), 1-12.

Afenyo, E. A., \& Amuquandoh, F. E. (2014). Who benefits from community-based ecotourism development? Insights from Tafi Atome, Ghana. Tourism Planning \& Development, 11(2), 179-190.

Appiah-Opoku, S. (2011). Using protected areas as a tool for biodiversity conservation and ecotourism: A case study of Kakum National Park in Ghana. Society and Natural Resources, 24(5), 500-510.

Ashley C., and Roe, D. (1998). Enhancing community development in wildlife tourism: Issue and challenges, IIED Wildlife and Development Series no: 11. London: International Institute for Environment and Development. 
Blackstock, K. (2005). A critical look at community based tourism. Community Development Journal, 40(1), 39-49

Botes, L \& Rensburg, D. van. (2000). Community participation in development: nine plagues and twelve commandments. Community Development Journal, 35 (1), $41-58$.

Bretty, E.A. (2003) Participation and accountability in development management. The Journal of Development Studies, 40 (2), 1-29.

Brodie, E, Cowling, E \& Nissen, N (2009). Understanding Participation: A Literature Review. Retrieved from National Council for Voluntary Organisations website: ht tp://www.ivr.org.uk/images/stories/Institute-of-Volunteering-Research/MigratedResources/Documents/U/Pathways-literature-review-final-version.pdf.

Byrd, E. T. (2003). An Analysis of Variables That Influence Stakeholder stakeholder participation and support for sustainable tourism development in rural North Carolina, (Unpublished doctoral thesis). North Carolina State University.

Chok, S., Macbeth, J., \& Warren, C. (2007). Tourism as a tool for poverty alleviation: A critical analysis of 'pro-poor tourism'and implications for sustainability. Current Issues in Tourism, 10(2-3), 144-165.

Cole, S. (2006). Cultural tourism, community participation and empowerment In M.K. Smith \& M., Robinson (Eds.), Cultural tourism in a changing world: politics, participation and (re)presentation (pp. 89-103). Buffalo, NY: Channel View Publications.

Dei, L.A. (2000). Community participation in tourism in Africa. In P. Dieke (Ed.), Political economy of tourism in Africa (pp. 6-18). New York: Congnizant publication.

Drumm, A. (1998). New approaches to community-based ecotourism management' In: K. Lindberg, M.E. Wood \& D. Engeldrum (Eds.). Ecotourism, a guide for planners and managers, 2, The Ecotourism Society: North Bennington, Vermont.

Easterling, D. (2005). The residents' perspective in tourism research. Journal of Travel \& Tourism Marketing 17(4), 45-62.

Eshun, G., \& Tonto, J. N. P. (2014). Community-based ecotourism: its socioeconomic impacts at Boabeng-fiema Monkey Sanctuary, Ghana. Bulletin of Geography. Socio-economic Series, 26(26), 67-81.

Goodman, R. M., Speers, M. A., McLeroy, K., Fawcett, S., Kegler, M., Parker, E., \& Wallerstein, N. (1998). Identifying and defining the dimensions of community capacity to provide a basis for measurement. Health Education and Behavior, 25(3), 258-278.

Greene, S (2005). Including young mothers: community-based participation and the continuum of active citizenship. Community Development Journal, 42(2), 167180.

Guijt, I. and Shah, M.K. (Eds.) (1998). The Myth of Community: Gender issues in participatory development. London: ITDG Publishing.

Gursoy D, Jurowski C \& Uysal M (2002). Resident attitudes: A structural modelling approach. Annals of Tourism Research, 29(1), 79-105.

Harrill, R. (2004). Residents' attitudes toward tourism development: A literature review with implications for tourism planning. Journal of Planning Literature, 18(3), 251-266.

Hibbard, M., \& Lurie, S. (2000). Saving land but losing ground: Challenges to community planning in the era of participation. Journal of Planning Education and Research, 20, 187-195. 
Hung, K., Sirakaya-Turk, E., \& Ingram, L. J. (2011). Testing the efficacy of an integrative model for community participation. Journal of Travel Research, 50(3), 276-288.

Jaafar, M., Rasoolimanesh, S. M., \& Ismail, S. (2015). Perceived sociocultural impacts of tourism and community participation: A case study of Langkawi Island. Tourism and Hospitality Research, [Online before print] DOI: 10.1177/ 1467358415610373.

Khazaei, A., Elliot, S., \& Joppe, M.(2015). An application of stakeholder theory to advance community participation in tourism planning: the case for engaging immigrants as fringe stakeholders. Journal of Sustainable Tourism, 23(7), 10491062.

Kibicho, W. (2008). Community-based tourism: A factor-cluster segmentation approach. Journal of Sustainable Tourism, 16(2), 211-231.

Ko, D., \& Stewart, W. (2002) A structural equation model of residents' attitudes for tourism development. Tourism Management 23(5), 521-530.

Kumar, S. (2002). Methods for Community Participation: A complete guide for practitioners. London: ITDG Publishing.

La'tkova', P. \& Vogt, C. (2012). Residents' attitudes toward existing and future tourism development in rural communities. Journal of Travel Research 51(1), $50-67$.

Manderson, L., Valencia, L.B. and Thomas, B. (1992). Bringing the people in: Community participation and the control of tropical disease. Resource Paper No. 1, Social and Economic Research in Tropical Diseases. TDR/SER/RP/92/1. Geneva:UNDP/World Bank/WHO Special Programme for Research and Training in Tropical Diseases.

Manu, I., \& Kuuder, C. J. W. (2012). Community-based ecotourism and livelihood enhancement in Sirigu, Ghana. International Journal of Humanities and Social Science, 2(18), 97-108.

Maraga, J. N., Kibwage, J. K., \& Oindo, B. O. (2010). Factors determining community participation in afforestation projects in River Nyando basin, Kenya. African Journal of Environmental Science and Technology, 4(12), 853-859.

McIntosh, R.W., \& Goeldner, G.R. (1986). Tourism: Principles, Practices, Philosophies (5 ed.). New York: Wiley.

McLaughlin, C. M. (2011). People living in protected areas: a comparative study of the social impacts of conservation in Latin America's Mamirau Sustainable Development Reserve and Racelest Biosphere Reserve, (Unpublished masters dissertation). American University United Nations University for Peace.

Mehta, J. N., \& Heinen, J. T. (2001). Does community-based conservation shape favourable attitudes among locals? An empirical study from Nepal. Environmental Management, 28(2), 165-177.

Mehta, J. N., \& Kellert, S. R. (1998). Local attitudes toward community-based conservation policy and programmes in Nepal: a case study in the Makalu-Barun Conservation Area. Environmental Conservation, 25(04), 320-333.

Mensah, I., \& Adofo, E. (2013). Community Participation in Ecotourism: The Case of Bobiri Forest Reserve and Butterfly Sanctuary in Ashanti Region of Ghana. American Journal of Tourism Management, 2(A), 34-42.

Midgley, J. (1986). Community participation: History, concepts, and controversies. In J. Midgley, A. Hall, M. Hardiman \& D. Narine (Eds.). Community participation, social development and the State (pp. 13-44). London: Methuen. 
Nicholas L, Thapa B and Ko, Y. (2009). Residents' perspectives of a world heritage site: The Pitons Management Area, St. Lucia. Annals of Tourism Research 36(3), 390-412.

Nyaupane, G. P., Morais, D. B., \& Dowler, L. (2006). The role of community involvement and number/type of visitors on tourism impacts: A controlled comparison of Annapurna, Nepal and Northwest Yunnan, China. Tourism Management, 27(6), 1373-1385.

Odege, D. W. (2014). Factors influencing community participation in cultural tourism at Kit Mikayi in Kisumu County, Kenya (Unpublished masters dissertation). University of Nairobi, Nairobi, Kenya.

Page, S. J., Thorn, K., Hall, C. M., \& Lew, A. A. (1998). Sustainable tourism development and planning in New Zealand: local government responses. Sustainable Tourism: A Geographical Perspective, 173-184.

Patton, M. (1990). Qualitative Evaluation and Research Methods (2nd ed.), London: Sage.

Safari, J., Gowele, V., \& Lwelamira, J. (2015). Involvement in tourism activities and perceived benefits in communities around Udzungwa Mountain National Park in Tanzania, American Journal of Environmental Protection. 4(3), 120-126.

Salleh, N. H. M., Shukor, M. S., Othman, R., Samsudin, M., \& Idris, S. H. M. (2016). Factors of local community participation in tourism-related business: Case of Langkawi Island. International Journal of Social Science and Humanity, 6(8), 565 .

Schafft, K \& Greenwood, D (2003). Promises and dilemmas of participation: Action research, search conference methodology, and community development, Journal of the Community Development Society, 34 (1), 18- 35.

Simmons, D. G. (1994). Community participation in tourism planning. Tourism Management, 15 (2), 98-108.

Theodori, G.L. (2005). Community and community development in resource-based areas: operational definitions rooted in an interactional perspective. Society and Natural Resources, 18, 661-669.

Timothy, D. J. (1999). Participatory planning: A view of tourism in Indonesia. Annals of Tourism Research 26(2), 371-391.

Tosun, C. (2000). Limits to community participation in the tourism development process in developing countries. Tourism management, 21(6), 613-633.

Tosun, C. (2006). Expected nature of community participation in tourism development. Tourism Management, 27(3), 493-504.

Tosun, C. (2005). Stages in the emergence of a participatory tourism development approach in the developing world. Geoforum, 36(3), 333-352.

Trakolis, D. (2001). Local people's perceptions of planning and management issues in Prespes Lakes National Park, Greece. Journal of Environmental Management, 61(3), 227-241.

Wang, Y., Pfister, R. E., \& Morais, D. B. (2007). Residents' attitudes toward tourism development: a case study of Washington, NC. Proceedings of the 2006 Northeastern Recreation Research Symposium. April 9-11, 2006, United States Department of Agriculture, Forest Service, Northern Research Station.

Yeboah, T. (2013). Assessing community participation in selected ecotourism projects in the Brong-Ahafo Region, Ghana. Journal of Ecology and the Natural Environment, 5(7), 133-143.

Yoon, Y., Chen, J.S., \& Gursoy, D. (1999). An Investigation of the relationship between tourism impacts and host communities' characteristics. Anatolia: An International Journal of Tourism and Hospitality Research, 10 (1), 29-44. 
Zhao, W., \& Ritchie, J.B. (2007). Tourism and poverty alleviation: An integrative research framework. Current Issues in Tourism, 10(2), 119-143. 